\title{
Mazowieckie sejmiki lipcowe w 1733 roku wobec kandydatury Piasta na tron polski
}

\begin{abstract}
Abstrakt: W artykule ukazano przebieg sejmików relacyjnych w województwie mazowieckim, które zostały zwołane po zakończonym sejmie konwokacyjnym 1733 roku. Przedstawiono również stosunek sejmikującej szlachty poszczególnych ziem do uchwalonego na tym sejmie aktu konfederacji generalnej wykluczającego cudzoziemca od tronu polskiego.

Słowa kluczowe: województwo mazowieckie, bezkrólewie 1733 roku, Stanisław Leszczyński, sejmiki lipcowe, popisy szlachty
\end{abstract}

Ważnym wydarzeniem mającym wpływ na kształtowanie się obozu narodowego w województwie mazowieckim w okresie przedostatniego bezkrólewia - oprócz marcowych sejmików przedsejmowych i sejmu konwokacyjnego (zob. Aneks, tabela 1) - były także sejmiki relacyjne w tym województwie, które rozpoczęły obrady 7 lipca 1733 roku. Podobnie jak w przypadku sejmików przedsejmowych $\mathrm{z}$ tego roku, tak i o sejmikach relacyjnych w województwie mazowieckim niewiele jest informacji w literaturze przedmiotu. Symboliczne wiadomości można znaleźć w publikacji Szymona Askenazego ${ }^{1}$. Spośród współczesnych historyków problematyką tych sejmików zajął się Bronisław Wojciechowski, który jednak skupił się tylko na sejmiku ziemi łomżyńskiej². Niniejszy artykuł jest więc próbą szerszego ukazania postawy szlachty na sejmikach lipcowych. Niestety, nie udało się dotrzeć do laud sejmików ciechanowskiego i wyszogrodzkiego, jednak dostępne informacje pozwalają na wyciągnięcie istotnych konkluzji również w odniesieniu do nich.

\footnotetext{
${ }^{1}$ S. Askenazy: Przedostatnie bezkrólewie. W: Idem: Dwa stulecia XVIII i XIX. Badania i przyczynki. T. 1. Warszawa 1901.

2 B. Wojciechowski: Ignacy Przyjemski starosta łomżyński polityk lokalny czasów saskich. Olsztyn 2004.
} 
Sejmikująca szlachta ziemi czerskiej zgodnie wybrała na sejmiku marszałka, którym został stronnik Stanisława Leszczyńskiego, starościc czerski Antoni Jan Rostworowski ${ }^{3}$. Następnie złożyła przysięgę na akt ustanowionej na sejmie konfederacji $^{4}$ - wbrew twierdzeniom biskupa krakowskiego Jana Aleksandra Lipskiego (adherenta elektora saskiego), jakoby przysięga została odłożona ${ }^{5}$. Szlachta miała być nakłaniana do tego - jak donosił poseł saski Joseph Antoni Wackerbarth-Salmour w liście do wojewody podlaskiego Michała Sapiehy ${ }^{6}$ - przez kasztelana czerskiego Kazimierza Rudzińskiego, który miał na to nie żałować pieniędzy ${ }^{7}$. Sejmikująca szlachta czerska także pod wpływem kasztelana czerskiego sprzeciwiła się promowaniu na tron polski jakiegokolwiek kandydata austriackiego czy moskiewskiego: „cudzoziemca nie godzi się promować, Polaka tylko”8. Zakazano brania od cudzoziemców pieniędzy, kto by to zaś czynił, miał być uważany za zdrajcę i wroga ojczyzny ${ }^{9}$. W rzeczy samej, szlachta powtórnie opowiedziała się za utrzymaniem wolnej elekcji i szybkim wyborem marszałka na sejmie elekcyjnym, zapowiadając przybycie na sejm pospolitym ruszeniem. Na sejmiku zgodnie wybrano także posłów na sejm elekcyjny, którzy mieli wziąć udział w wyborze marszałka sejmu

${ }^{3}$ Antoni Jan Rostworowski, syn Jana Wiktoryna, w okresie bezkrólewia zaangażowany po stronie Stanisława Leszczyńskiego, marszałek sejmiku antykonwokacyjnego czerskiego, poseł na sejm elekcyjny, elektor Stanisława Leszczyńskiego, w 1734 roku przystąpił do partykularnej konfederacji ziemi czerskiej, opowiadającej się po stronie Stanisława Leszczyńskiego; dopiero w 1738 roku otrzymał urząd starosty czerskiego. Z. Zielińska: Rostworowski Antoni Jan. W: Polski słownik biograficzny (dalej: PSB). T. 32. Wrocław 1989, s. 177-178.

${ }^{4}$ Należy zauważyć, że kto by tej przysięgi nie złożył, miał być wykluczony z udziału w elekcji nowego króla. Biblioteka Narodowa w Warszawie (dalej: BN), rkps 6668, k. 31v, Gazeta pisana z Warszawy, 26 V 1733; Biblioteka Naukowa Polskiej Akademii Umiejętności i Polskiej Akademii Nauk w Krakowie (dalej: BPAU i PAN), Teki Pawińskiego (dalej: TP), rkps 8320, k. 278, Laudum sejmiku relacyjnego czerskiego, 7 VII 1733.

${ }^{5}$ Gorliwy stronnik Sasa, doradca posłów saskich w Warszawie, współtwórca konfederacji warszawskiej opowiadającej się po stronie Augusta III. Archiwum Główne Akt Dawnych (dalej: AGAD), Archiwum Publiczne Potockich (dalej: APP), rkps 169, s. 471v, J. Lipski do T. Lubomirskiego, Warszawa 15 VII 1733; J. Gierowski: Lipski Jan Aleksander. W: PSB. T. 17. Wrocław 1972, s. 428.

${ }^{6}$ Szerzej o postawie wojewody podlaskiego zob. A. LiSeK: Działalność polityczna wojewody podlaskiego Michała Józefa Sapiehy i innych przedstawicieli tego Domu w okresie powtórnej elekcji Stanisława Leszczyńskiego w 1733 roku. W: Sapiehowie epoki Kodnia i Krasiczyna. Red. K. STĘPNiK. Lublin 2007, s. 420-428.

7 Biblioteka Książąt Czartoryskich (dalej: BCzart.), rkps 2896, k. 381, J.A. Wackerbarth-Salmour i W.H. Baudissin do M.J. Sapiehy, Warszawa 12 VII 1733. Już 25 sierpnia 1733 roku podczas obrad sejmu elekcyjnego miał podpisać manifest domagający się wyboru Stanisława Leszczyńskiego. W. Majewski, W. Rudziński: Rudziński Kazimierz. W: PSB. T. 33. Wrocław 1991-1992, s. 22.

${ }^{8}$ Pozostałe informacje bp. Jana Lipskiego co do odłożenia przysięgi na sejmiku ziemi łomżyńskiej, nurskiej, wyszogrodzkiej i zakroczymskiej są w pełni wiarygodne. AGAD, APP, rkps 169, k. 471v, J. Lipski do T. Lubomirskiego, Warszawa 15 VII 1733; ibidem, k. 482v, J. Lipski do T. Lubomirskiego, Warszawa 15 VII 1733.

${ }^{9}$ BCzart., rkps 2896, k. 381, J.A. Wackerbarth-Salmour i W.H. Baudissin do M.J. Sapiehy, Warszawa 12 VII 1733. 
elekcyjnego. Pierwszym posłem został starościc czerski Jan Rostworowski, stronnik S. Leszczyńskiego ${ }^{10}$. Łącznie wybrano 50 osób.

Zarazem na sejmiku ziemi czerskiej postanowiono, że popisy pocztów tamtejszej szlachty odbędą się 10 sierpnia 1733 roku pod Czerskiem. Wskazano przy tym, że wszystkie powiaty „do pułkowej i innych chorągwi powiatowych” miały wystawić po 25 osób. Do czego zachęcał szlachtę swymi uniwersałami kasztelan czerski K. Rudziński. Gdyby liczba pocztów była większa niż potrzeba do popisu, miały one być podporządkowane kasztelanowi czerskiemu ${ }^{11}$. Po zakończonym sejmiku 18 lipca 1733 roku posłowie czerscy zostali przyjęci na audiencji u prymasa Teodora Potockiego ${ }^{12}$.

Relacyjny sejmik ziemi warszawskiej rozpoczął obrady w kościele św. Marcina. Przybyli nań książę Michał Fryderyk Czartoryski, podkanclerzy litewski; Franciszek Maksymilian Ossoliński, podskarbi wielki koronny; Jerzy August Mniszech, łowczy koronny. Wszyscy ci dygnitarze zaliczani byli do obozu stanisławowskiego. Marszałkiem sejmiku został ponownie Stanisław Sobolewski, pisarz ziemski warszawski, wcześniejszy marszałek skonfederowanego sejmiku przedkonwokacyjnego warszawskiego ${ }^{13}$. Zanim doszło do zagajenia obrad, pod wpływem zgromadzonej szlachty z udziału w nich wykluczono rezydenta brandenburskiego Karola Gottfrieda Hoff-

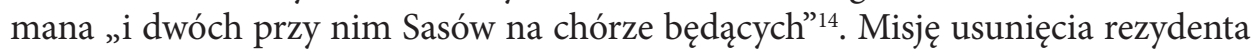
powierzono m.in. podkanclerzemu litewskiemu M.F. Czartoryskiemu ${ }^{15}$ i ppłk. regimentu dragonii Janowi Kazimierzowi Turnowi. Nie obyło się bez protestów rezydenta brandenburskiego, który zamierzał poskarżyć się królowi Fryderykowi Wilhelmowi I na bezprawne, jego zdaniem, działania. W tej sytuacji marszałek sejmiku S. Sobolewski ponownie posłał do niego swego przedstawiciela regenta warszawskiego Sokolskiego, aby jednak ustąpił. Ostatecznie poseł pruski ustąpił i opuścił sejmik. Po czym wysłuchano relacji posłów delegowanych na sejm konwokacyjny i przystąpiono do składania przysięgi na akt konfederacji generalnej uchwalonej na sejmie ${ }^{16}$.

\footnotetext{
${ }^{10}$ Jan Rostworowski, starosta czerski, złożył swój podpis pod aktem konfederacji dzikowskiej 1734 roku jako marszałek ziemi czerskiej.

${ }_{11}$ BPAU i PAN, TP, rkps 8320, k. 278v, Laudum sejmiku relacyjnego, Czersk 7 VII 1733.

12 Z Warszawy d. 23 Julii 1733. W: Od Augusta Mocnego do Augusta III. Doniesienia $z$ Warszawy Andrzeja Cichockiego z lat 1732-1734. Wyd. J. Dygda£A. Warszawa 2016, s. 303.

${ }_{13}$ Stanisław Sobolewski - jego postawa w czasie elekcji w 1733 roku nie jest znana, brak jego podpisu pod kandydaturą Stanisława Leszczyńskiego czy Augusta III. D. Dukwicz: Sobolewski Stanisław. W: PSB. T. 39. Warszawa 1999, s. 590; Biblioteka Jagiellońska (dalej: BJ), rkps 5718, k. 506v, NN do NN, [b.m. i b.d.]; BCzart., Muzeum Narodowe w Krakowie (dalej: MNK), rkps 50, k. 397, Relacja o sejmiku post convokacyjnym ziemi warszawskiej, Warszawa 7 VII 1733.

${ }^{14}$ Sejmik obradował w kościele św. Marcina, por. Z Warszawy d. 9 Julii 1733. W: Od Augusta Mocnego do Augusta III..., s. 295.

${ }^{15}$ W. Konopczyński: Czartoryski Michał Fryderyk. W: PSB. T. 4. Kraków 1938, s. 289-290.

${ }_{16}$ BCzart., rkps 2896, k. 381, J.A. Wackerbarth-Salmour i W.H. Baudissin do M.J. Sapiehy, Warszawa 12 VII 1733; Z Warszawy d. 9 Julii 1733. W: Od Augusta Mocnego do Augusta III..., s. 296.
} 
Pierwszy przysięgę złożył marszałek S. Sobolewski, później jeszcze raz zrobili to posłowie, którzy byli na sejmie konwokacyjnym, następnie urzędnicy i szlachta zgromadzona na sejmiku: „po 6 po 10 razem przystępowali”. Część szlachty chciała odłożyć przysięgę do sejmu elekcyjnego, ostatecznie jednak — pod wpływem nacisku i agitacji stronników S. Leszczyńskiego, w tym podskarbiego wielkiego koronnego F.M. Ossolińskiego ${ }^{17}$ i podkanclerzego litewskiego księcia M.F. Czartoryskiego, przekonujących, by nie ulegać hasłom dworu saskiego - w większości ją złożyła. Tak więc tylko nieliczna szlachta rozjechała się do swoich stancji, nie składając przysięgi ${ }^{18}$, wbrew niektórym doniesieniom zawartym $\mathrm{w}$ gazecie pisanej $\mathrm{z}$ Warszawy, jakoby wielu przedstawicieli szlachty miało wyjść z kościoła ${ }^{19}$. Także w laudum ziemi warszawskiej z 18 sierpnia 1733 roku była mowa, że na popisie ziemi warszawskiej obowiązku złożenia przysięgi dopełniło zaledwie 9 osób: podczaszy warszawski Józef Czosnowski, podstoli Józef Sobolewski, skarbnik Jan Kozakiewicz, Franciszek Siemiaszko, Kazimierz Sarnowicz, Aleksander Fezyński, chorąży Rzeczypospolitej Michał Chołkowski, starościc wyszogrodzki Kazimierz Szymanowski, kapitan Rzeczypospolitej Józef Szymanowski ${ }^{20}$. Łącznie podpis złożyło na sejmiku ok. 220 osób $^{21}$. Był to niewątpliwie sukces obozu narodowego S. Leszczyńskiego.

Po odczytaniu listów przysłanych na sejmik przez prymasa T. Potockiego i wojewodę mazowieckiego Stanisława Poniatowskiego ${ }^{22}$ głos zabrał m.in. miecznik warszawski Adam Szamocki (stronnik S. Leszczyńskiego) ${ }^{23}$, który pod wpływem Antoniego Eperyasza, starosty skiertymońskiego (komisarza królewicza Jakuba Sobieskiego $)^{24}$, zarzucił komisarzom saskim, że nie płacą długów i „przyobiecanej

17 Szerzej o jego postawie w okresie bezkrólewia zob.: K. KAnTeCKi: Franciszek Maksymilian Ossoliński, podskarbi wielki koronny. Warszawa 1880, s. 13.

${ }_{18}$ BCzart., MNK, rkps 50, k. 399v, Relacja o sejmiku post convokacyjnym ziemi warszawskiej, Warszawa 7 VII 1733; AGAD, Archiwum Radziwiłłów (dalej: AR), dz. XXXXIV, rkps 350, k. 3, Gazeta pisana z Warszawy 9 VII 1733.

19 AGAD, AR, dz. XXXXIV, rkps 350, k. 3, Gazeta pisana z Warszawy 9 VII 1733.

${ }^{20}$ BPAU i PAN, TP, rkps 8334, k. 181, Oblata laudum ziemi warszawskiej, Warszawa 18 VIII 1733.

${ }^{21} \mathrm{~W}$ świetle doniesień gazety pisanej z Warszawy przysięgę na konwokację na sejmiku ziemi warszawskiej miało złożyć 228 osób. Biblioteka Uniwersytetu Warszawskiego (dalej: BUW), rkps 716, nl., Gazeta pisana z Warszawy 9 VII 1733.

${ }^{22}$ Przed rozpoczynającymi się sejmikami relacyjnymi wojewoda mazowiecki Stanisław Poniatowski miał przebywać w Solcu. BCzart., rkps 574, k. 229, T. Potocki do S. Poniatowskiego, [b.m.] 12 VI 1733.

${ }^{23}$ BCzart., MNK, rkps 50, k. 401v, Relacja o sejmiku post convokacyjnym ziemi warszawskiej, Warszawa 7 VII 1733; szerzej o postawie Stanisława Poniatowskiego zob.: Z. ZIELIŃsKa: Walka „Familii” o reformę Rzeczypospolitej 1743-1752. Warszawa 1983, s. 15-18.

${ }^{24}$ Antoni Eperyasz, starosta skiertymoński, aktywnie popierał Stanisława Leszczyńskiego w okresie wojny o tron polski w latach 1733-1736, zob. A. LISEK: Obóz stanistawowski w województwie ruskim w okresie bezkrólewia i wojny o tron polski w latach 1733-1736. Kraków 2014, s. 127 (przypis 371). 
satysfakcji saris odrzuciwszy, fakcje teraz robią i paszkwile piszą" ${ }^{25}$. Zdaniem Jerzego Dygdały, chodziło tu o pismo pt. „List pewnego Posła do Przyjaciela swego pisany”, którego autorem był stronnik saski w Polsce Antoni Sebastian Dembowski, referendarz koronny ${ }^{26}$. W druku tym zarzucono m.in. prymasowi T. Potockiemu przynależność do fakcji francuskiej - co było prawdą - i przymuszanie szlachty na sejmie konwokacyjnym do złożenia przysięgi ${ }^{27}$. Paweł Zambrzycki postulował na sejmiku, ażeby paszkwil kat publicznie spalił28, a posłowie sascy wyjechali do Krakowa, grandmuszkieterowie zaś, którzy nie chcieli przysiąc na wierność Rzeczypospolitej, do trzech tygodni opuścili Warszawę ${ }^{29}$. Także Urgebat domagał się, aby komisarze sascy, którzy nie pełnili funkcji posłów, opuścili Warszawę. Zabiegano o to u prymasa T. Potockiego. Ostatecznie prymas postanowił, by kat spalił wzmiankowany druk ${ }^{30}$.

Zaznaczyć trzeba, że w celu wyboru pułkownika i rotmistrzów, którzy mieli prowadzić szlachtę na sejm elekcyjny, doszło do spotkania przedstawicieli szlachty w klasztorze oo. Augustynów jeszcze przed rozpoczynającym się sejmikiem ${ }^{31}$. Ponieważ rywalizacja o te funkcje była duża, rozmowy nie doprowadziły do ostatecznego wyłonienia kandydatów. Także w pierwszym dniu obrad sejmiku to się nie udało, dlatego odłożono elekcję rotmistrzów na dzień następny. Nad sposobem ich wyboru szlachta miała długo obradować, gdyż — jak twierdził metrykant koronny Andrzej Cichocki - jedni domagali się ich wyłonienia większością głosów, drudzy

${ }^{25}$ Niejaki ksiądz Ignacy Lasowski z Ujazdowa miał zeznać na sejmiku warszawskim, że za pieniądze od posła saskiego J.A. Wackerbartha-Salmoura rozdawał wśród znajomych drukowane paszkwile przeciwko postanowieniom sejmu konwokacyjnego. Poseł saski zaprzeczał jednak temu, zarzucając księdzu pijaństwo i imbecylizm, obwiniając za wszystko prymasa T. Potockiego. BCzart., rkps 2896, k. 381, J.A. Wackerbarth-Salmour i W.H. Baudissin do M.J. Sapiehy, Warszawa 12 VII 1733; AGAD, APP, rkps 169, k. 182, J. Lipski do T. Lubomirskiego, Warszawa 8 VII 1733.

${ }^{26}$ Już przed sejmem konwokacyjnym płk Karl von Unruh zaliczał go do stronników obozu saskiego, proponując skierowanie go na Mazowsze w celu agitacji na rzecz elektora saskiego. J. DYGDAŁA: Saskie próby infiltracji środowisk szlacheckich podczas bezkrólewia 1733 roku. „Kwartalnik Historyczny” 2003, R. 110, z. 4, s. 49-50; S. Askenazy: Przedostatnie..., s. 107; W. KonopCzy Ński: Dembowski Antoni Sebastian. W: PSB. T. 5. Kraków 1939, s. 84.

${ }_{27}$ Z Warszawy d. 9 Julii 1733. W: Od Augusta Mocnego do Augusta III..., s. 296.

${ }_{28}$ Ostatecznie pismo zostało spalone przez kata w „smolnych pochodniach”. „Kurier Polski” 1733, nr 186.

${ }^{29}$ Nalegania szlachty na złożenie przysięgi przez grandmuszkieterów wynikały z obawy, że mogą być oni wykorzystani przez obóz saski w zabiegach o zdobycie tronu dla Fryderyka Augusta II. W rzeczy samej taka była także intencja zmarłego króla Augusta II. Część z nich zaraz po złożonej przysiędze opuściło szeregi muszkieterów, tylko nieliczni udali się do Drezna. M. MATUszEwICz: Diariusz życia mego. T. 1: 1714-1757. Oprac. B. Królı́owski. Warszawa 1986, s. 50-51; J. STAszewski: Grandmuszkieterowie Augusta II. Nowa wersja. „Sobótka” 1982, nr 3-4, s. 470.

${ }^{30}$ BCzart., rkps 2896, k. 381, J.A. Wackerbarth-Salmour i W.H. Baudissin do M.J. Sapiehy, Warszawa 12 VII 1733.

31 BCzart., MNK, rkps 50, k. 397, Relacja o sejmiku post convokacyjnym ziemi warszawskiej, Warszawa 7 VII 1733. 
przez powiaty, a jeszcze inni dopiero na sierpniowym popisie. Dopiero w trzecim dniu obrad (18 sierpnia) wybrano na pułkownika Macieja Szymanowskiego, starostę wyszogrodzkiego ${ }^{32}$. Rotmistrzami zaś zostali Józef Okęcki, stolnik warszawski, i Kazimierz Potrykowski, chorąży różański3i.

18 sierpnia 1733 roku zgromadzona na popisie szlachta wyłoniła także posłów do szopy na polu elekcyjnym. W gronie tym znalazły się osoby, które dopiero co złożyły przysięgę na uchwaloną konfederację. Z powiatu warszawskiego wybrano 24 posłów, z powiatu błońskiego 24 i z powiatu tarczyńskiego 21 . W sumie ustanowiono 69 posłów, którzy mieli wziąć udział w wyborze marszałka sejmu elekcyjnego.

Sejmikowi relacyjnemu w Wiznie marszałkował Adam Stanisław Rostkowski, starosta wiski ${ }^{34}$. Na wstępie wysłuchano relacji posłów z sejmu konwokacyjnego. Po czym zgromadzona szlachta w obecności marszałka skonfederowanego sejmiku złożyła przysięgę na akt uchwalonej na sejmie konfederacji. Wybrano posłów do prymasa T. Potockiego, którymi zostali Paweł Karwowski, podczaszy wiski, i Teofil Kossakowski, łowczy ziemi wiskiej ${ }^{35}$. Ustanowiono wyprawę - stukonną chorągiew $^{36}$ - na którą uchwalono podatek poborowy z dóbr ziemskich: po 8 zł z włóki, na jednego żołnierza konnego - po 100 tynfów. Nałożono także podatek na Żydów: od każdego Żyda -2 tynfy, od Żydówki -1 tynf, zaś od służby -3 tynfy. Zakazano przy tym Żydom zatrudniania katolików do służby. Duktorem chorągwi obrano marszałka skonfederowanego sejmiku A. Rostkowskiego, starostę wiskiego (wyznaczono go także na posła na sejm elekcyjny). Choragiew ta miała trwać przy marszałku w dyscyplinie i w porządku aż do końca elekcji ${ }^{37}$.

W czasie obrad sejmiku relacyjnego wyszogrodzkiego szlachta miała odłożyć przysięgę na uchwalony akt konfederacji generalnej do momentu zebrania się na

${ }^{32}$ Maciej Szymanowski, starosta wyszogrodzki, na sejmie elekcyjnym nie złożył podpisu pod żadnym z kandydatów. 5 października 1733 roku przystąpił do konfederacji warszawskiej opowiadającej się po stronie króla Augusta III. Poseł na sejm koronacyjny w 1734 roku do Krakowa. BN, akc., rkps 9114, k. 9, Gazety pisane nadsyłane do I. Przyjemskiego, starosty łomżyńskiego, Warszawa 18 XI 1734; A. Haraty M, Z. Zielińska: Szymanowski Maciej. W: PSB. T. 50. Warszawa 2014, s. 89.

${ }^{33}$ Andrzej Cichowski w gazecie pisanej błędnie przypisał funkcję rotmistrza staroście wyszogrodzkiemu Maciejowi Szymanowskiemu. Zarówno „Kurier Polski”, jak i laudum sejmiku zaprzeczają temu. BPAU i PAN, TP, rkps 8334, s. 181, Oblata laudum ziemi warszawskiej, Warszawa 18 VIII 1733; „Kurier Polski” 1733, nr 186; Z Warszawy d. 9 Julii 1733. W: Od Augusta Mocnego do Augusta III..., s. 297.

${ }^{34}$ Marszałek skonfederowanej ziemi wiskiej, elektor Stanisława Leszczyńskiego z województwa mazowieckiego. E. BURDA: Rostkowski Adam Stanisław. W: PSB. T. 32. Wrocław 1989, s. 162.

${ }^{35}$ Celem poselstwa było poinformować prymasa T. Potockiego o stratach i szkodach poczynionych w ziemi wiskiej przez Prusy. W. Szczygielski: Karwowski Paweł. W: PSB. T. 12. Wrocław 1966, s. 167.

${ }^{36}$ BPAU i PAN, TP, rkps 8351, s. 138, Laudum conventus particularis Wiznensis, 7 VII 1733.

${ }^{37}$ W laudum sejmiku wizneńskiego znajdującym się w Tekach Pawińskiego wymieniono 18 sędziów, liczba ta nie jest jednak kompletna. Ibidem, s. 135. 
polu elekcyjnym. Potwierdzają to doniesienia z 23 lipca 1733 roku komisarzy saskich: J.A. Wackerbartha-Salmoura i generała W.H. Baudissina oraz gazety pisane metrykanta koronnego A. Cichockiego ${ }^{38}$.

Sejmik relacyjny zakroczymski obradował pod laską marszałkowską Władysława Łazniewskiego, chorążego czernihowskiego i elektora S. Leszczyńskiego. Na sejmiku wybrano mu do pomocy wcześniej naznaczonego pułkownika i dwóch rotmistrzów: Antoniego Radzickiego, sędziego ziemskiego zakroczymskiego ${ }^{39}$, i Józefa Wągrodzkiego, podczaszego ziemi zakroczymskiej. Sejmik podjął także decyzję o obowiązkowym dostarczeniu ludzi do tworzonych chorągwi, które miały ruszyć na pole elekcyjne. Skądinąd do wystawienia ludzi zobowiązana została nie tylko szlachta, lecz także duchowieństwo, m.in. biskup płocki z Pułtuska i innych swoich dóbr znajdujących się w ziemi zakroczymskiej wystawił 6 pachołków, opat czerwieński -2 pachołków, klasztor czerwieński z Olszyna, Nowej Wsi, Domostowia, Powielina -2 pachołków ${ }^{40}$.

Sejmikująca szlachta ziemi zakroczymskiej nie złożyła jednak przysięgi na uchwaloną na sejmie generalną konfederację ${ }^{41}$. Uczyniło to tylko kilka osób: Felicjan Kuczborski, podkomorzy zakroczymski, Sebastian Chodubski, pisarz zakroczymski, i Kazimierz Goławiński. Według metrykanta koronnego A. Cichockiego, przysięgę miało złożyć tylko 5 osób, reszta zadeklarowała, że zrobi to dopiero na popisie ${ }^{42}$. Sejmik został limitowany.

Szlachta ziemi ciechanowskiej nie przysięgła na sejmiku relacyjnym na ekskluzję cudzoziemca uchwaloną na generalnej konfederacji warszawskiej ${ }^{43}$. Na sejmiku doszło bowiem do tumultu i rozlewu krwi (byli liczni ranni). Część sejmikujących wystąpiła przeciwko staroście ciechanowskiemu Józefowi Nakwaskiemu, który miał

${ }^{38}$ BCzart., rkps 1982, k. 135, J.A. Wackerbarth-Salmour i W.H. Baudissin do elektora saskiego Fryderyka Augusta II, Warszawa 23 VII 1733; Z Warszawy d. 16 Julii 1733. W: Od Augusta Mocnego do Augusta III..., s. 299; 23 Julii 1733. W: Od Augusta Mocnego do Augusta III..., s. 302; AGAD, APP, rkps 169, k. 471v, J. Lipski do T. Lubomirskiego, Warszawa 15 VII 1733. Szymon Askenazy w swej pracy podaje, że w województwie mazowieckim szlachta nie złożyła przysięgi tylko na 4 sejmikach: ciechanowskim, zakroczymskim, nurskim i wyszogrodzkim. Pomija sejmik ziemi łomżyńskiej, na którym także nie złożono przysięgi, zob. S. Askenazy: Przedostatnie..., s. 120.

39 Stronnik Stanisława Leszczyńskiego, przystąpił on z całą pewnością do obozu saskiego już 9 listopada 1735 roku, co potwierdza jego udział w tym dniu w obradach walnej rady konfederacji warszawskiej zawiązanej przy boku króla Augusta III.

40 BPAU i PAN, TP, rkps 8354, s. 18, Laudum sejmiku relacyjnego, Zakroczym 7 VII 1733.

41 S. Askenazy: Przedostatnie..., s. 120; BCzart., rkps 1982, k. 135, J.A. Wackerbarth-Salmour i W.H. Baudissin do elektora saskiego Fryderyka Augusta II, Warszawa 23 VII 1733; AGAD, APP, rkps 169, s. 471v, J. Lipski do T. Lubomirskiego, Warszawa 15 VII 1733; V.J. GerJe: Borba za Pol'skij prestoł v 1733 godu. Moskva 1862, s. 349.

${ }^{42}$ BCzart., rkps 1982, k. 135, J.A. Wackerbarth-Salmour i W.H. Baudissin do elektora saskiego Fryderyka Augusta II, Warszawa 23 VII 1733; „Kurier Polski” 1733, nr 189; Z Warszawy d. 16 Julii 1733. W: Od Augusta Mocnego do Augusta III..., s. 299; S. AskenAzy: Przedostatnie..., s. 120.

43 S. Askenazy: Przedostatnie..., s. 120; V.J. Gerje: Borba za Pol'skij prestoł..., s. 349. 
wyrazić zgodę na złożenie przysięgi, oraz przeciwko staroście jaworowskiemu Franciszkowi Radzimińskiemu, który wraz ze swymi stronnikami ledwo zdołał uciec konno z sejmiku ${ }^{44}$. W tej sytuacji sejmik nie podjął żadnej decyzji i się rozszedł ${ }^{45}$. W świetle doniesień „Kuriera Polskiego” szlachta miała złożyć przysięgę dopiero na popisie ${ }^{46}$.

Sejmik relacyjny ziemi różańskiej obradował w Różanie pod marszałkostwem podczaszego różańskiego Michała Zorawskiego (elektora S. Leszczyńskiego na sejmie elekcyjnym). Asesorami jego zostali Jan Gostkowski, cześnik różański, i Józef Ciemniewski ${ }^{47}$. Szlachta skupiona na sejmiku relacyjnym ziemi różańskiej złożyła przysięgę zgodnie z konfederacją na wykluczenie cudzoziemca od korony ${ }^{48}$. Ci, którzy tego nie uczynili z powodu absencji, mieli to zrobić na popisie lub na sejmie elekcyjnym. Na sejmiku wybrano 25 posłów na przyszły sejm elekcyjny. Wyznaczono również termin zwołania popisów pod Dysząbabą na 1 sierpnia 1733 roku, wtedy też miano dokonać wyboru pułkowników, rotmistrzów i poruczników, którzy poprowadzą szlachtę na sejm elekcyjny. Na sejmiku zdominowanym przez stronników S. Leszczyńskiego potępiono zdecydowanie wszystkich, którzy potajemnie współpracowali z ministrami państw ościennych i szukali sposobów wprowadzenia wojsk cudzoziemskich do Rzeczypospolitej, grożąc im konfiskatą majątku i oddaniem pod sąd kapturu generalnego ${ }^{49}$.

1 sierpnia szlachta różańska zebrała się na popisie. Przysięgę złożyli wówczas ci, którzy wcześniej tego nie uczynili. Wybrano także pułkowników - dwóch stronników S. Leszczyńskiego: Błażeja Krasińskiego, starostę prosnyskiego i nowomiejskiego, oraz Wojciecha Przeradowskiego, starostę różańskiego i makowskiego. Rotmistrzem został Michał Zorawski, podczaszy różański, a porucznikiem - Jan Rzechowski, pisarz grodzki różański ${ }^{50}$. Także oni byli związani z obozem stanisławowskim, w czasie elekcji oddali swoje głosy na S. Leszczyńskiego. Ponadto na popisie ostatecznie ustalono, że część szlachty przybędzie na pole viritim, inni zaś $\mathrm{z}$ wyprawą.

${ }^{44}$ BCzart., rkps 2896, k. 381, J.A. Wackerbarth-Salmour i W.H. Baudissin do M.J. Sapiehy, Warszawa 12 VII 1733; Z Warszawy d. 16 Julii 1733. W: Od Augusta Mocnego do Augusta III..., s. 300.

${ }^{45}$ BCzart., rkps 1982, k. 135, J.A. Wackerbarth-Salmour i W.H. Baudissin do elektora saskiego Fryderyka Augusta II, Warszawa 23 VII 1733.

${ }^{46}$ AGAD, Zbiór Ignacego Przyjemskiego (dalej: ZIP), t. 8, k. 129, K. Rudziński do I. Przyjemskiego, Warszawa 30 VII 1733; AGAD, APP, rkps 169, k. 316, J. Lipski do T. Lubomirskiego, [b.m.] 5 VIII 1733; „Kurier Polski” 1733, nr 189; Z Warszawy d. 6 Augustii 1733. W: Od Augusta Mocnego do Augusta III..., s. 309.

${ }^{47}$ Konsyliarz partykularnej konfederacji zawiązanej 1734 roku u boku S. Leszczyńskiego. BPAU i PAN, TP, rkps 8337, s. 444, Laudum conventus particularis rozanensis, Różan 7 VII 1733.

${ }^{48}$ Z Warszawy d. 16 Julii 1733. W: Od Augusta Mocnego do Augusta III..., s. 299.

${ }_{49}$ BPAU i PAN, TP, rkps 8337, s. 502, Laudum popisu, Dyszababa 4 VIII 1733.

${ }^{50}$ Jan Rzechowski, stronnik S. Leszczyńskiego, wziął udział w 1734 roku w zawiązanej przy jego boku partykularnej konfederacji. 
Szlachta ziemi liwskiej zjechała się na sejmik relacyjny — za wcześniejszym uniwersałem prymasa T. Potockiego - z hasłami utrzymania wszelkich praw i bezpieczeństwa Rzeczypospolitej. Marszałkiem sejmiku wybrano Karola Dąbrowskiego, regenta ziemi grodzkiej liwskiej. Część szlachty wraz z marszałkiem (48 osób) złożyła przysięgę na akt uchwalonej konfederacji. Ci zaś, którzy tego nie zrobili, mieli to uczynić na popisie wyznaczonym na 17 sierpnia pod Liwem ${ }^{51}$. Zapewne nastąpiło to pod dużym wpływem stronników S. Leszczyńskiego. Nie przypadkiem więc pisał pijar Ignacy Konarski, „iż nie ma co myśleć o przeciąganiu tej szlachty na stronę saską, gdyż pełno wśród niej krewnych kasztelana czerskiego K.F. Rudzińskiego i partyzantów Czartoryskich"52. Ponadto na sejmiku uchwalono pobór ludzi do chorągwi pułkowej z dóbr biskupich i królewskich — po jednym pachołku z dziesięcin i włók, którzy mieli stawić się pod Ożarowem. W laudum potępiono wszystkich, którzy utrzymywali kontakty z państwami cudzoziemskimi — przez ich ministrów - i działali na szkodę i zgubę Rzeczypospolitej. Krytykując ich zamiar wprowadzenia do Rzeczypospolitej obcych wojsk pod pozorem obrony liberum veto, domagano się konfiskowania im dóbr ziemskich ${ }^{53}$.

Sejmik relacyjny ziemi łomżyńskiej obradował pod skonfederowaną laską marszałkowską Ignacego Przyjemskiego, starosty łomżyńskiego ${ }^{54}$. Na samym początku sejmik odmówił ustanowienia podatków (czopowego i szelężnego) na wcześniej uchwalone 4 chorągwie, które miały się udać na pole elekcyjne ${ }^{55}$. Mogło to nastąpić, jak twierdził B. Wojciechowski, pod wpływem niechęci szlachty do dodatkowych obciążeń lub na skutek rywalizacji między marszałkiem sejmiku a chorążym łomżyńskim Janem Staniszewskim, o czym donosił sam starosta łomżyński biskupowi krakowskiemu J.A. Lipskiemu ${ }^{56}$. W tej sytuacji J. Staniszewski, który wcześniej został

51 Szlachta miała się zebrać na popisie za dyspozycją kasztelana liwskiego Adama Ciecirzowskiego, który został zarazem obrany pułkownikiem ziemi liwskiej. BPAU i PAN, TP, rkps 8322, s. 440, Laudum sejmiku relacyjnego ziemi liwskiej, Liw 7 VII 1733.

52 J. DygdaŁa: Saskie próby infiltracji..., s. 57.

53 Por. BPAU i PAN, TP, rkps 8322, s. 440, Laudum sejmiku relacyjnego ziemi liwskiej, Liw 7 VII 1733.

54 Jeszcze przed dojściem sejmiku do skutku stronnicy starosty łomżyńskiego I. Przyjemskiego deklarowali się nie dopuścić jego konkurenta chorążego łomżyńskiego J. Staniszewskiego do funkcji marszałkowskiej, jak widać działania te były skuteczne. AGAD, ZIP, t. 8, k. 112, A.P. Rostkowski do I. Przyjemskiego, [Warszawa?] 2 VII 1733.

55 Z włóki szlacheckiej szlachta miała dać po 5 zł. Każdy gospodarz i komornik, także Żyd, miał zapłacić od osób swoich 8 zł. Zaś miasto Łomża świadczące różne usługi w okresie bezkrólewia miało być zwolnione z tych podatków, por. BPAU i PAN, TP, rkps 8332, s. 265, Laudum sejmiku relacyjnego łomżyńskiego, Łomża 7 VII 1733.

${ }^{56}$ Doniesienia o braku pieniędzy z czopowego i szelężnego na chorągwie, AGAD, ZIP, t. 8, k. 121, I. Przyjemski do J. Staniszewskiego, [b.m.] 16 VII 1733; ibidem, k. 124, I. Przyjemski do J.A. Lipskiego, Kupska 8 VII 1733. Rywalizacja spotkała się z krytyką marszałka wielkiego koronnego J.W. Mniszcha, stronnika Stanisława Leszczyńskiego, zabiegającego o utrzymanie spokoju 
wybrany na porucznika ziemi łomżyńskiej, nie widząc możliwości powołania chorągwi, zrezygnował z tej funkcji. Zastąpił go jego dotychczasowy rywal I. Przyjemski, który ostatecznie uformował chorągwie i zorganizował ich popis na błoniach pod miastem ${ }^{57}$. Na sejmiku wybrano ok. 30 posłów na sejm elekcyjny, wśród nich oprócz marszałka I. Przyjemskiego znalazł się także stronnik Sasa - łowczy łomżyński Michał Maurycy Suski. Miał on utrzymywać stałe kontakty z komisarzami saskimi (od których miał otrzymać beczkę wina i tabakierkę) ${ }^{58}$.

Pomimo że już na początku laudum sejmiku relacyjnego szlachta wyraziła nadzieję na wybór na przyszłym sejmie elekcyjnym Polaka („Wszyscy obstawali pozornie przy królu rodaku, »wyprzysięgli« się cudzoziemców”), to jednak na sejmiku nie złożono przysięgi na uchwaloną konfederację, odkładając ją do sejmu elekcyjnego ${ }^{59}$. Stąd zaniepokojenie kasztelana K. Rudzińskiego, czego wyraz dał w liście do marszałka I. Przyjemskiego, pisząc, że po województwach do jedności się zbierają, „Niemca się wyprzysięgają, a Polaka za pana per omnia mieć sobie życzą," a w ziemi łomżyńskiej pojawiły się fakcje i scysje, z których cieszyć się mieli Niemcy. Dalej pisał: „,niech nas Bóg broni, ażebyśmy potem nie płakali nad utratą wolności, gdy nie mamy jedności”" ${ }^{\prime \prime}$. Także marszałek wielki koronny Józef Wandalin Mniszech apelował o uspokojenie i zaniechanie waśni na sejmiku między I. Przyjemskim a chorążym łomżyńskim J. Staniszewskim. W odpowiedzi na przywołany list marszałek sejmiku obwiniał za całe zamieszanie chorążego łomżyńskiego. W tej sytuacji wojewoda mazowiecki S. Poniatowski (cieszący się dużą popularnością wśród szlachty) ${ }^{61}$ i kasztelan czerski K. Rudziński zaproponowali I. Przyjemskiemu złożenie przysięgi nie na polu elekcyjnym, lecz na popisie, by uniknąć scysji w okresie poprzedzającym

wewnętrznego w Rzeczypospolitej, dlatego naciskał on na Ignacego Przyjemskiego o zakończenie konfliktu, ibidem, t. 8, k. 118, J.W. Mniszech do I. Przyjemskiego, [b.m.] 30 VI 1733; B. WojcieCHоwsкi: Ignacy Przyjemski..., s. 33.

${ }^{57} \mathrm{Na}$ sejmie elekcyjnym nie złożył on podpisu pod żadnym z kandydatów do tronu polskiego, przyjął postawę wyczekiwania, nie angażując się po żadnej ze stron w obawie o swój majątek. Nie przystąpił on również do partykularnej konfederacji łomżyńskiej zawiązanej 20 stycznia 1734 roku, zob. B. Wojciechowski: Ignacy Przyjemski..., s. 33-34.

${ }^{58}$ J. Dygda£a: Saskie próby infiltracji..., s. 63.

59 Przegląd wojsk miał być zorganizowany przez Ignacego Przyjemskiego na błoniach pod miastem, zob. B. Wojciechowsкi: Ignacy Przyjemski..., s. 33; BPAU i PAN, TP, rkps 8332, s. 266, Laudum sejmiku relacyjnego łomżyńskiego, Łomża 7 VII 1733; AGAD, APP, rkps 169, k. 471, J. Lipski do T. Lubomirskiego, Warszawa 15 VII 1733; S. Askenazy: Przedostatnie..., s. 120; A. LiseK: Działalność polityczna..., s. 422; Z Warszawy d. 23 Julii 1733. W: Od Augusta Mocnego do Augusta III..., s. 302.

${ }^{60}$ AGAD, ZIP, t. 8, k. 118, J.W. Mniszech do I. Przyjemskiego, [b.m.] 30 VII 1733; ibidem, k. 122, K. Rudziński do I. Przyjemskiego, Warszawa 30 VII 1733.

${ }^{61}$ J. DygdaŁa: Postawa „familii” Czartoryskich w bezkrólewiu 1733 roku z perspektywy Wiednia. W: Między wielka polityka a szlacheckim partykularyzmem. Studia $z$ dziejów nowożytnej Polski i Europy. Red. K. WAJDA et al. Toruń 1993, s. 282. 
sejm elekcyjny lub w czasie jego trwania ${ }^{62}$. Propozycja ta była jednak spóźniona. I. Przyjemski zwrócił bowiem uwagę, że popisy się już odbyły i doszło na nich, w szczególności w powiecie zambrowskim, do scysji podczas składania przysięgi ${ }^{63}$. Obawiając się jednak wydawania uniwersału na generalny popis, deklarował w tej sprawie porozumieć się z urzędnikami ziemi łomżyńskiej, tak „aby tak lex publika jako i laudum nasze nie były w niczym naruszone”, bez których zgody, jak twierdził, nic nie mógł uczynić64 ${ }^{4}$ Zdania swego nie zmienił nawet pod wpływem próśb i obietnic składanych mu przez prymasa T. Potockiego ${ }^{65}$. Ostatecznie, jak sądzić można, szlachta łomżyńska nie złożyła przysięgi, odkładając to do czasu zebrania się na polu elekcyjnym.

Sejmik relacyjny w Nurze obradował pod marszałkostwem Stanisława Gąsiorowskiego, podstolego ziemi nurskiej. Na asesorów wybrano: Jana Pieńkowskiego, sędziego kapturowego ziemi nurskiej, Kazimierza Duczminskiego, chorążego znaku pancernego, sędziego kapturowego. Sejmik, jak donoszono w „Kurierze Polskim”: „przy zgodnej harmonii stanął”. Według wojewody podlaskiego Michała Sapiehy ${ }^{66}$ miało jednak dojść na nim do zaburzeń z powodu łamania w jego trakcie wolnego głosu i z powodów przysięgi. Stało się to przyczyną odłożenia przysięgi na akt uchwalonej konfederacji aż do sejmu elekcyjnego, co potwierdzają lauda sejmikowe ziemi nurskiej. Na sejmiku wybrano posłów na sejm elekcyjny i trzech rotmistrzów,

${ }^{62}$ Podobne propozycje złożył kasztelan Rudziński skłóconemu z Przyjemskim chorążemu łomżyńskiemu Janowi Staniszewskiemu, do którego miał także żal za niedopełnienie przysięgi, pisząc: „[... nie wiem za co nie mogłeś nakłonić co prawo każe do potwierdzenia generalnej konfederacji. Mnie by się zdało, gdybyś WMPan zabierał się sam w przód satisfaciendo legi do wykonania, to rozumiem [...] musieliby się nakłonić wszyscy". Rudziński krytycznie odniósł się także w liście do jego sporu ze starostą łomżyńskim. Jego zdaniem miało to zły wpływ na atmosferę panującą na sejmiku, AGAD, ZIP, t. 2, k. 743, K. Rudziński do J. Staniszewskiego, Warszawa 30 VII 1733; AGAD, ZIP, t. 8, k. 126-127, S. Poniatowski do I. Przyjemskiego, Solec 26 VII 1733; ibidem, k. 128, K. Rudziński do I. Przyjemskiego, Warszawa 30 VII 1733.

${ }^{63}$ Napięcie polityczne i konflikty fakcyjne w ziemi łomżyńskiej spowodowały, że w przypadku zwołania kolejnego popisu Antoni Rostkowski, podczaszy łomżyński, zalecał w celu uniknięcia waśni i sporów, aby powiaty nie były skupione na jednym miejscu. On sam także nie życzył sobie bliskiego sąsiedztwa chorążego łomżyńskiego J. Staniszewskiego, AGAD, ZIP, t. 8, k. 134, A. Rostkowski do I. Przyjemskiego, 5 VIII 1733.

${ }^{64}$ AGAD, ZIP, t. 8, k. 127, I. Przyjemski do S. Poniatowskiego, Kupiska 3 VIII 1733.

65 Ibidem, k. 131, T. Potocki do I. Przyjemskiego, [Warszawa?] 31 VII 1733; ibidem, k. 131, I. Przyjemski do T. Potockiego, Kupiska 3 VIII 1733. Także Michał Czartoryski, podkanclerzy wielki litewski, opowiadający się po stronie Stanisława Leszczyńskiego, krytykował I. Przyjemskiego za niezłożenie przysięgi na sejmiku, jego zdaniem tak potrzebnej dla utrzymania jedności w Rzeczypospolitej, zachęcając go do złożenia przysięgi przez ziemię łomżyńską jeszcze przed sejmem elekcyjnym na popisie, ibidem, k. 132, M. Czartoryski do I. Przyjemskiego, Warszawa 31 VII 1733.

${ }^{66}$ AGAD, Archiwum Ordynacji Roskiej (dalej: AOR), Pudło LVI/6, k. 373, M. Sapieha do J. Sapiehy, Siemiatycze [?] VIII 1733. 
którzy mieli prowadzić szlachtę z trzech powiatów: nurskiego, ostrowskiego i kamienieckiego ${ }^{67}$.

Na popisie w polu w dniu 16 lipca 1733 roku pod Nurem — jak donosił „Kurier Polski” - miał się prezentować powiat przed starostą nurskim Krzysztofem Godlewskim, który zabiegał o zachowanie jedności w powiecie. Niewątpliwie był on stronnikiem S. Leszczyńskiego, na sejmie elekcyjnym oddał na niego swój głos (chociaż wcześniej zaliczany był przez komisarzy saskich do ewentualnych stronników Sasa $)^{68}$. Szlachta przybyła na popis miała liczyć 3 tys. osób, liczba ta wydaje się jednak zawyżona. Zebrani mieli niemal jednogłośnie poprzeć „Króla Polaka z Ojca i Matki rodowitego"69.

Popis powiatu kamienieckiego odbył się 29 lipca 1733 roku, także w tym przypadku udział szlachty był liczny. Wśród zgromadzonych było wielu urzędników, m.in. marszałek S. Gąsiorowski, podstoli ziemi nurskiej; Jan Lipski, wojski nurski; Antoni Wodziński, podstoli ziemi liwskiej; Andrzej Godlewski, miecznikowicz liwski; Michał Pudłowski, sędzia ziemi zakroczymskiej; Antoni Zdzieborski, skarbnik nowogrodzki; Stanisław Lipiński, regent ziemski i grodzki kamieniecki; Kazimierz Mierzyński, podwojewodzi ziemi nurskiej; Antoni Kozłowski, stolnikowicz owru$\mathrm{cki}^{70}$. W trakcie popisu miały się prezentować 34 osoby ze swoimi pocztami. Następnie szlachta przystąpiła do wyboru oficerów chorągwi. Porucznikiem obrano Antoniego Zdzieborskiego, skarbnika, chorążym natomiast został Mikołaj Płudowski, sędzia zakroczymski. Ustalono ponadto, że szlachta miała ruszyć na pole elekcyjne za ordynansem Jakuba Floriana Narzymskiego, podkomorzego i pułkownika ${ }^{71}$. Szlachta na popisie opowiedziała się także za wyborem na króla tylko Polaka, co potwierdziła przysięgą na akt generalnej konfederacji złożoną na polu elekcyjnym. Uczyniła to także szlachta powiatu ostrowskiego zebrana na popisie w Ostrowi 4 sierpnia 1733 roku $^{72} .20$ sierpnia szlachta powiatu nurskiego i kamienieckiego stanęła $\mathrm{z}$ chorągwiami pod Warszawą, opowiadając się powtórnie za kandydaturą Polaka, złożyła także przysięgę na akt konfederacji. Wśród zgromadzonych byli

${ }^{67}$ AGAD, AOR, Pudło VI/6, k. 374, M. Sapieha do J. Sapiehy, [b.m.] [?] 1733; BPAU i PAN, TP, rkps 8335, s. 205, Laudum cum limitatione ziemi nurskiej, Nur 7 VII 1733; BCzart., rkps 1982, k. 135, J.A. Wackerbarth-Salmour i W.H. Baudissin do elektora saskiego Fryderyka Augusta II, Warszawa 23 VII 1733; AGAD, APP, rkps 169, k. 471, J. Lipski do T. Lubomirskiego, Warszawa 15 VII 1733; Z Warszawy d. 23 Julii 1733. W: Od Augusta Mocnego do Augusta III..., s. 302.

68 J. DygdaŁa: Saskie próby infiltracji..., s. 58.

69 „Kurier Polski” 1733, nr 188.

70 BPAU i PAN, TP, rkps 8335, s. 207, Laudum popisu powiatu kamienieckiego, Kamieniec 29 VIII 1733.

${ }^{71}$ Po prześcigu na Pragę w czasie elekcji poparł Augusta III, przystępując do konfederacji warszawskiej. Za zasługi dla dworu saskiego otrzymał 24 października 1734 roku urząd wojewody czernihowskiego. W. Szczygielski: Narzymski Jakub Florian. W: PSB. T. 22. Wrocław 1977, s. 581.

72 BPAU i PAN, TP, rkps 8335, s. 122, Laudum conventus particularis ostroviensis, 4 VIII 1733. 
marszałek S. Gąsiorowski, podstoli ziemi nurskiej, i kasztelan czerski K. Rudziński, zagorzały stronnik S. Leszczyńskiego ${ }^{73}$.

Reasumując, sejmiki relacyjne z roku 1733 - pomimo zabiegów prymasa T. Potockiego i wojewody mazowieckiego S. Poniatowskiego - nie przebiegały spokojnie. Ich obrady stały się sceną ostrej rywalizacji stronnictw, uwidoczniły też podział opinii publicznej ${ }^{74}$. Obóz saski na sejmikach w województwie mazowieckim odniósł niewątpliwie pewien sukces. Po części dzięki wsparciu finansowemu ze strony dworów saskiego, rosyjskiego i austriackiego, sprzeciwiających się kandydaturze S. Leszczyńskiego, oraz narastającym obawom przed interwencją ze strony państw ościennych, podsycanych przez stronników Sasa. Aż 5 sejmików relacyjnych (wyszogrodzki, zakroczymski, ciechanowski, łomżyński i nurski), czyli połowa, odłożyło złożenie przysięgi na akt konfederacji. Nie udało się temu zapobiec - jak słusznie zauważył Szymon Askenazy - wojewodzie mazowieckiemu S. Poniatowskiemu. Taki rozwój sytuacji niewątpliwie nie przekreślał nadziei stronników Sasa na osadzenie na tronie polskim elektora Fryderyka Augusta II. Warto zauważyć, że odkładanie na sejmikach przysięgi i podziały sejmikującej szlachty nie były czymś odosobnionym i niezgodnym z postanowieniami sejmu konwokacyjnego, który dopuszczał możliwość złożenia przysięgi jeszcze na początku elekcji. Do podobnych sytuacji doszło m.in. w województwach podlaskim, ruskim, wołyńskim, kijowskim i na sejmiku egzulanckim województwa czernihowskiego we Włodzimierzu Wołyńskim $^{75}$. Na podkreślenie zasługuje fakt, że szlachta sejmików łomżyńskiego i zakroczymskiego, która przed sejmem konwokacyjnym poparła kandydaturę Polaka, na sejmikach elekcyjnych nie złożyła przysięgi. Z kolei przysięgę złożono na sejmikach: czerskim, warszawskim, wiskim, różańskim i liwskim.

Taki układ sił nie był jednak trwały, chociaż stanowił poważne ostrzeżenie dla obozu stanisławowskiego. Część szlachty, zapewne pod wpływem wzrastającej świadomości narodowej oraz wzmożonej agitacji wojewody mazowieckiego, kasztelana czerskiego i innych stronników obozu narodowego, jeszcze przed sejmem elekcyjnym złożyła przysięgę na popisach, np. ziemia ciechanowska i nurska. W ten sposób chwilowa równowaga sił w województwie mazowieckim została zaburzona jeszcze przed sejmem elekcyjnym na korzyść obozu narodowego S. Leszczyńskiego. Z zestawienia umieszczonego w Aneksie (tabele 2 i 3) wynika, że najbardziej stabilny elektorat kandydata narodowego był na sejmiku przedsejmowym i relacyjnym w Czersku, Warszawie i Liwie. Sejmiki te poparły zarówno kandydaturę Polaka na

${ }^{73}$ Ibidem, rkps 8335, s. 215, Laudum powiatu nurskiego i kamienieckiego pod Warszawą, 20 VIII 1733.

${ }^{74}$ BJ, rkps 122/51, k. 209, List Prymasa T. Potockiego na sejmiki relacyjne in ordine do sejmu elekcyjnego, Warszawa 22 VII 1733.

${ }^{75}$ A. LiseK: Z badań nad postawa polityczna szlachty województwa czernihowskiego i kijowskiego w latach 1733-1736. „Limes. Studia i materiały z dziejów Europy Środkowo-Wschodniej” 2014, nr 7, s. 65 . 
tron polski na sejmikach przedkonwokacyjnych, jak i złożyły przysięgę na uchwaloną konfederację. Podczas obrad sejmików relacyjnych, podobnie jak na sejmikach przedkonwokacyjnych, nie obyło się także bez rywalizacji o funkcję marszałkowską, m.in. na sejmikach ciechanowskim i nurskim. Rywalizacja zakończyła się jednak zwycięstwem stronników S. Leszczyńskiego.

Na sejmikach relacyjnych dokonano także wyboru posłów na sejm elekcyjny. Liczba ich była zróżnicowana w poszczególnych ziemiach, i tak np. na sejmiku w Czersku wybrano ich 50, w Warszawie - 69, w Różanie - 25, w Łomży - 30 i w Liwie - 46. W gronie tym znalazło się wielu stronników obozu stanisławowskiego. Przykładowo spośród 25 posłów z ziemi różańskiej aż 22 oddało głos na S. Leszczyńskiego ${ }^{76}$, na sejmiku łomżyńskim na 30 posłów 15 oddało głos na S. Leszczyńskiego. Niestety, stan źródeł nie pozwala określić dokładnej liczby wszystkich posłów wybranych na sejmikach relacyjnych. Trudno także oszacować, jaka była frekwencja na sejmikach relacyjnych, z pewnością była ona jednak dość znaczna, podobnie jak na sejmikach przedkonwokacyjnych.

\section{Aneks}

Tabela 1

Posłowie z województwa mazowieckiego na sejm konwokacyjny w 1733 roku

\begin{tabular}{|l|l|}
\hline \multicolumn{1}{|c|}{$\begin{array}{c}\text { Ziemie } \\
\text { województwa mazowieckiego }\end{array}$} & \multicolumn{1}{|c|}{ Posłowie } \\
\hline czerska & $\begin{array}{l}\text { Franciszek Rudziński, starosta kruszwicki } \\
\text { Kasper Suffczyński, podstoli czerski }\end{array}$ \\
\hline warszawska & $\begin{array}{l}\text { Jan Mniszech, starosta jaworowski } \\
\text { Franciszek Kalisz, miecznik gostyński }\end{array}$ \\
\hline wiska & $\begin{array}{l}\text { Szymon Olszyński, podkomorzy wiski } \\
\text { Felicjan Świderski, stolnik wiski }\end{array}$ \\
\hline wyszogrodzka & $\begin{array}{l}\text { Maciej Szymanowski, starosta wyszogrodzki } \\
\text { Franciszek Nakwaski, pisarz ziemski wyszogrodzki }\end{array}$ \\
\hline zakroczymska & $\begin{array}{l}\text { Antoni Radzicki, sędzia ziemski zakroczymski } \\
\text { Józef Wągrodzki, podczaszy ziemi zakroczymskiej }\end{array}$ \\
\hline ciechanowska & $\begin{array}{l}\text { Michał Nieborowski, podkomorzy ciechanowski } \\
\text { Kazimierz Brzozowski, pisarz ziemski i grodzki ciechanowski }\end{array}$ \\
\hline łomżyńska & $\begin{array}{l}\text { Tomasz Zieliński, podkomorzyc łomżyński } \\
\text { Michał Maurycy Suski, łowczy łomżyński }\end{array}$ \\
\hline
\end{tabular}

${ }^{76} \mathrm{~W}$ stosunku tylko do niewielkiej liczby posłów (3) nie udało się ustalić ich stanowiska na sejmie elekcyjnym. 
cd. tab. 1

\begin{tabular}{|l|l|}
\hline różańska & $\begin{array}{l}\text { Błażej Krasiński, przasnyski, nowomiejski starosta } \\
\text { Jan Rzechowski, pisarz grodzki rożański }\end{array}$ \\
\hline liwska & $\begin{array}{l}\text { Józef Oborski, podkomorzy liwski } \\
\text { Fabian Zukowski, skarbnik ziemi liwskiej }\end{array}$ \\
\hline nurska & $\begin{array}{l}\text { Jakub Narzymski, podkomorzy nurski } \\
\text { Krzysztof Godlewski, starosta ziemi nurskiej }\end{array}$ \\
\hline
\end{tabular}

Źródło: Opracowanie własne na podstawie: Volumina Legum. T. 6. Wyd. J. OHrYzko. Petersburg 1860; „Kurier Polski” 1733, nr 1859.

Tabela 2

Sejmiki przedsejmowe w województwie mazowieckim w 1733 roku

\begin{tabular}{|c|c|c|c|}
\hline Lp. & Miejsce obrad & Marszałkowie partykularnych sejmików & $\begin{array}{l}\text { Stanowisko wobec kandydatury Piasta } \\
\text { do tronu polskiego }\end{array}$ \\
\hline 1. & Czersk & $\begin{array}{l}\text { Antoni Karczewski, pisarz ziemski } \\
\text { czerski }\end{array}$ & $\begin{array}{l}\text { za kandydaturą Polaka na tron } \\
\text { polski }\end{array}$ \\
\hline 2. & Warszawa & $\begin{array}{l}\text { Stanisław Sobolewski, pisarz ziemski } \\
\text { warszawski }\end{array}$ & $\begin{array}{l}\text { za kandydaturą Polaka na tron } \\
\text { polski }\end{array}$ \\
\hline 3. & Wizno & $\begin{array}{l}\text { Adam Stanisław Rostkowski, starosta } \\
\text { wiski }\end{array}$ & $\begin{array}{l}\text { brak jednoznacznego poparcia } \\
\text { dla kandydatury Polaka }\end{array}$ \\
\hline 4. & Wyszogród & [?] Szawłowski, podstoli wyszogrodzki & $\begin{array}{l}\text { brak jednoznacznego poparcia } \\
\text { dla kandydatury Polaka }\end{array}$ \\
\hline 5. & Zakroczym & $\begin{array}{l}\text { sejmik rozdwojony, wybrano dwóch } \\
\text { marszałków: } \\
\text { Dymitr Lasocki, miecznik zakroczymski } \\
\text { Franciszek Zaborowski, skarbnik } \\
\text { zakroczymski }\end{array}$ & $\begin{array}{l}\text { za kandydaturą Polaka na tron } \\
\text { polski }\end{array}$ \\
\hline 6. & Ciechanów & $\begin{array}{l}\text { Adam Radzimiński, kasztelanic } \\
\text { ciechanowski }\end{array}$ & $\begin{array}{l}\text { brak jednoznacznego poparcia } \\
\text { dla kandydatury Polaka } \\
\end{array}$ \\
\hline 7. & Łomża & Ignacy Przyjemski, starosta łomżyński & $\begin{array}{l}\text { za kandydaturą Polaka na tron } \\
\text { polski }\end{array}$ \\
\hline 8. & Różana & $\begin{array}{l}\text { Wojciech Karski, } \\
\text { stolnik ziemi różańskiej i makowskiej }\end{array}$ & brak informacji \\
\hline 9. & Liw & $\begin{array}{l}\text { Karol Dąbrowski, regent grodzki ziemi } \\
\text { liwskiej }\end{array}$ & $\begin{array}{l}\text { za kandydaturą Polaka na tron } \\
\text { polski }\end{array}$ \\
\hline 10. & Nur & brak informacji & brak informacji \\
\hline
\end{tabular}

Źródło: Opracowanie własne na podstawie: BPAU i PAN, TP, rkps 8318, 8320, 8322, 8332, 8337, 8345, 8351, 8354, 1856; „Kurier Polski” 1733, nr 169; „Kurier Polski” 1733, nr 171; „Kurier Polski” 1733, nr 180. 
Tabela 3

Lipcowe sejmiki relacyjne w województwie mazowieckim

\begin{tabular}{|r|l|l|l|}
\hline Lp. & Miejsce obrad & \multicolumn{1}{|c|}{ Marszałkowie partykularnych sejmików } & \multicolumn{1}{|c|}{$\begin{array}{c}\text { Stosunek do przysięgi uchwalonej } \\
\text { na sejmie konwokacyjnym }\end{array}$} \\
\hline 1. & Czersk & Antoni Rostworowski, starościc czerski & $\begin{array}{l}\text { przysięga złożona na akt } \\
\text { konfederacji }\end{array}$ \\
\hline 2. & Warszawa & $\begin{array}{l}\text { Stanisław Sobolewski, pisarz ziemski } \\
\text { warszawski }\end{array}$ & $\begin{array}{l}\text { przysięga złożona na akt } \\
\text { konfederacji }\end{array}$ \\
\hline 3. & Wizno & $\begin{array}{l}\text { Adam Stanisław Rostkowski, starosta } \\
\text { wiski }\end{array}$ & $\begin{array}{l}\text { przysięga złożona na akt } \\
\text { konfederacji }\end{array}$ \\
\hline 4. & Wyszogród & brak informacji & $\begin{array}{l}\text { nie złożono przysięgi na akt } \\
\text { konfederacji }\end{array}$ \\
\hline 5. & Zakroczym & $\begin{array}{l}\text { Władysław Łazniewski, chorąży czerni- } \\
\text { howski }\end{array}$ & $\begin{array}{l}\text { nie złożono przysięgi na akt } \\
\text { konfederacji }\end{array}$ \\
\hline 6. & Ciechanów & brak informacji & $\begin{array}{l}\text { nie złożono przysięgi na akt } \\
\text { konfederacji }\end{array}$ \\
\hline 7. & Łomża & Ignacy Przyjemski, starosta łomżyński & $\begin{array}{l}\text { nie złożono przysięgi na akt } \\
\text { konfederacji }\end{array}$ \\
\hline 8. & Różana & Michał Zorawski, podczaszy różański & $\begin{array}{l}\text { przysięga złożona na akt } \\
\text { konfederacji }\end{array}$ \\
\hline 9. & Liw & $\begin{array}{l}\text { Karol Dąbrowski, regent grodzki ziemi } \\
\text { liwskiej }\end{array}$ & $\begin{array}{l}\text { przysięga złożona na akt } \\
\text { konfederacji }\end{array}$ \\
\hline 10. & Nur & $\begin{array}{l}\text { Stanisław Gąsiorowski, podstoli ziemi } \\
\text { nurskiej }\end{array}$ & $\begin{array}{l}\text { nie złożono przysięgi na akt } \\
\text { konfederacji }\end{array}$ \\
\hline
\end{tabular}

Źródło: Opracowanie własne na podstawie: BPAU i PAN, TP, rkps 8320, 8322, 8332, 8334, 8335, 8337, 8351, 8354; BCzart., MNK, rkps 50; „Kurier Polski” 1733, nr 188; „Kurier Polski” 1733, nr 189.

\section{Bibliografia}

Askenazy S.: Przedostatnie bezkrólewie. W: S. Askenazy: Dwa stulecia XVIII i XIX. Badania i przyczynki. T. 1. Warszawa 1901.

Burda E.: Rostkowski Adam Stanisław. W: Polski słownik biograficzny. T. 32. Wrocław 1989.

Dukwicz D.: Sobolewski Stanisław. W: Polski słownik biograficzny. T. 39. Warszawa 1999.

Dygda£A J.: Postawa „familii” Czartoryskich w bezkrólewiu 1733 roku z perspektywy Wiednia.

W: Między wielka polityka a szlacheckim partykularyzmem. Studia z dziejów nowożytnej Polski i Europy. Red. K. Wajda et al. Torun 1993.

DyGDAŁA J.: Saskie próby infiltracji środowisk szlacheckich podczas bezkrólewia 1733 roku. „Kwartalnik Historyczny" 2003, R. 110, z. 4, s. 47-70.

GerJe V.J.: Borba za Pol'skij prestołv 1733 godu. Moskva 1862.

Gierowski J.: Lipski Jan Aleksander. W: Polski słownik biograficzny. T. 17. Wrocław 1972.

Haratym A., Zielińska Z.: Szymanowski Maciej. W: Polski słownik biograficzny. T. 50, z 1. Warszawa 2014.

KANTECKi K.: Stanisław Poniatowski, kasztelan krakowski ojciec Stanisława Augusta. T. 2. Poznań 1880. 
Konopczyński W.: Czartoryski Michał Fryderyk. W: Polski słownik biograficzny. T. 4. Kraków 1938. Konopczyński W.: Dembowski Antoni Sebastian. W: Polski słownik biograficzny. T. 5. Kraków 1939.

LiseK A.: Działalność polityczna wojewody podlaskiego Michała Józefa Sapiehy i innych przedstawicieli tego Domu w okresie powtórnej elekcji Stanisława Leszczyńskiego w 1733 roku. W: Sapiehowie epoki Kodnia i Krasiczyna. Red. K. STęPNik. Lublin 2007.

LISEK A.: Obóz stanisławowski $w$ województwie ruskim w okresie bezkrólewia $i$ wojny o tron polski w latach 1773-1736. Kraków 2014.

LiseK A.: Z badań nad postawa polityczna szlachty województwa czernihowskiego i kijowskiego w latach 1733-1736. „Limes. Studia i materiały z dziejów Europy Środkowo-Wschodniej” 2014, nr 7, s. $60-86$.

Majewski W., Rudziński W.: Rudziński Kazimierz. W: Polski słownik biograficzny. T. 33. Wrocław 1991.

Matuszewicz M.: Diariusz życia mego. T. 1: 1714-1757. Oprac. B. Królikowski. Warszawa 1986.

Od Augusta Mocnego do Augusta III. Doniesienia z Warszawy Andrzeja Cichockiego z lat 1732-1734. Wyd. J. DygdaŁa. Warszawa 2016.

Staszewsкi J.: Grandmuszkieterowie Augusta II. Nowa wersja. „Sobótka” 1982, nr 3-4, s. 467-480.

SzczYgielski W.: Karwowski Pawet. W: Polski słownik biograficzny. T. 12. Wrocław 1966.

Szczygielski W.: Narzymski Jakub Florian. W: Polski słownik biograficzny. T. 2. Wrocław 1977.

Wojсіесношsкi B.: Ignacy Przyjemski (1703-87), starosta łomżyński 1730-74. Polityk lokalny czasów saskich. Olsztyn 2004.

Zielińska Z.: Rostworowski Antoni Jan. W: Polski słownik biograficzny. T. 32. Wrocław 1989.

Zielińska Z.: Walka „Familii” o reformę Rzeczypospolitej 1743-1752. Warszawa 1983.

Adam Lisek

The Masovian July dietines (sejmiks) of the year 1733 with regard to a Piast's bid to reign Poland

Summary

Despite the efforts of Primate Teodor Andrzej Potocki, the July relational dietines in the period of the penultimate interregnum became the battleground of cutthroat rivalry between the parties and factions present, which made the divisions amongst the public opinion conspicuous.

As much as a half of relational dietines (for the lands of Wyszogród, Zakroczym, Ciechanów, Łomża, and Nur) decided to postpone the vow-taking until the declaration of confederation was signed. What deserves to be underlined is the fact that upon two of the dietines, for the lands of Łomża and Zakroczym, the noblemen took vows despite their previous support for the Polish candidate during the Convocation Diet. Such a turn of events, though only temporarily, worked in favour of the Saxon camp, since it did not hurt the chances of a Saxon candidate ascending to the Polish throne. The endeavours in question were scuppered nonetheless, for after the popisy (a show of levies' military force), the noblemen representatives for the lands of Ciechanów and Nur vowed on the declaration of confederation adopted during the Convocation Diet, according to which a foreigner was to be excluded as a potential King of Poland.

Key words: Masovian voivodeship, the penultimate interregnum of the year 1733, Stanisław Leszczyński, July dietines (sejmiks), noblemen’s popisy 